Chirurgia (2021) 116: S97-S104

No. 5 Supplement, December

Copyright $\odot$ Celsius

http://dx.doi.org/10.21614/chirurgia.116.5 Suppl.S97

\title{
Systemic Treatment of Ductal Carcinoma In Situ of the Breast
}

\author{
Edoardo Crimini ${ }^{1,2}$, Chiara Corti ${ }^{1,2}$, Matteo Repetto ${ }^{1,2}$, Federica Giugliano ${ }^{1,2}$, Gabriele Antonarelli ${ }^{1,2}$, Paolo Tarantino ${ }^{1,2}$, \\ Paola Zagami ${ }^{1,2}$, Stefania Morganti ${ }^{1,2}$, Eleonora Nicolo ${ }^{1,2}$, Jacopo Uliano ${ }^{1,2}$, Giuseppe Curigliano $0^{1,2^{*}}$ \\ 'European Institute of Oncology, IRCCS, Milan, Italy \\ 2Department of Oncology and Hematology (DIPO), University of Milan, Milan, Italy
}

*Corresponding author: Giuseppe Curigliano, MD

Division of Early Drug Development for Innovative Therapy, IEO, European Institute of Oncology IRCCS, Milan, Italy

Department of Oncology and Hematology (DIPO), University of Milan, Milan, Italy

E-Mail: giuseppe.curigliano@ieo.it
Received: 21.10 .2021 Accepted: 26.11.2021

\begin{abstract}
Rezumat
Carcinomul ductal in situ (CDIS) este un tip de cancer mamar (CM) noninvaziv, a cărui incidență a crescut o dată cu implementarea programelor de screening pentru cancer de sân. CDIS reprezintă $20 \%$ din totalitatea cazurilor de CM. Aproximativ 70\% dintre pacientele diagnosticate cu CDIS prezintă receptori hormonali pozitivi, în timp ce doar $25-30 \%$ dintre acestea prezintă HER2 amplificat. În ceea ce priveşte terapia sistemică, conform ghidurilor NCCN, doar hormonoterapia (HT) ar trebui luată în considerare în cazul pacientelor cu CDIS. Mai mult decât atât, prognosticul excelent al acestui tip de cancer nu justifică utilizarea unui tratament mai agresiv de tipul terapiei anti-HER2 sau chimioterapiei. În acest articol abordăm rezultatele celor mai importante studii clinice în care au fost incluse paciente diagnosticate cu CDIS aflate în curs de terapie adjuvantă şi evaluare preoperatorie; în plus, am raportat rezultatele studiilor de prevenție cu HT, care au demonstrat o scădere a riscului de dezvoltare a CDIS. Pe de altă parte, decizia de a alege sau nu hormonoterapie adjuvantă, decizie îngreunată deseori de efectele adverse care duc la scăderea calității vieții pacientelor precum şi la lipsa complianței terapeutice, trebuie luată împreună cu pacienta, întrucât nu s-a demonstrat niciun avantaj în ceea ce priveşte rata de supraviețuire.
\end{abstract}

Cuvinte cheie: CDIS, terapia endocrină, cancer mamar, terapia hormonală

\section{Abstract}

Ductal carcinoma in situ (DCIS) is a noninvasive breast cancer 
(BC), whose diagnosis significatively increased with the diffusion of BC screening programs. DCIS actually represents roughly $20 \%$ of new BC diagnoses (1). About $70 \%$ of DCIS shows positivity for hormone receptor (HR), while HER2 is overexpressed in $25-30 \%$ of the cases (2,3). Concerning the systemic approach, the only one that should be considered for HR-positive DCIS is adjuvant endocrine therapy (ET), according to NCCN guidelines (4). In fact, the excellent prognosis of this neoplasm does not justify the utilization of more aggressive treatment strategies, such as HER2directed therapies or chemotherapy. Here we discuss the results of the most important clinical trials enrolling DCIS patients in the adjuvant and in the preoperative setting; in addition, we report the chemoprevention studies utilizing ET which demonstrated a reduction of the risk of DCIS development. On balance, the choice to undertake or not an adjuvant ET, which is often burdened by adverse events that could impact on the quality of life of the patients and on their adherence to the therapy, should be discussed with the patient, taking into account that no survival advantage has been demonstrated so far.

Key words: DCIS, endocrine therapy, breast cancer, carcinoma in situ, hormone therapy, chemoprevention

\section{Introduction}

Ductal carcinoma in situ (DCIS) is a non-invasive breast cancer (BC) limited to lactiferous ducts, whose diagnosis significatively increased after the introduction of $\mathrm{BC}$ screening programs, representing nowadays about $20 \%$ of new BC diagnoses (1). About 70\% of DCIS shows positivity for hormone receptors (HR), while Human Epidermal Growth Factor Receptor 2 (HER2) is overexpressed in $25-30 \%$ $(2,3)$. The natural history and the optimal management for DCIS remain controversial (Fig. 1). Not all patients with DCIS will develop

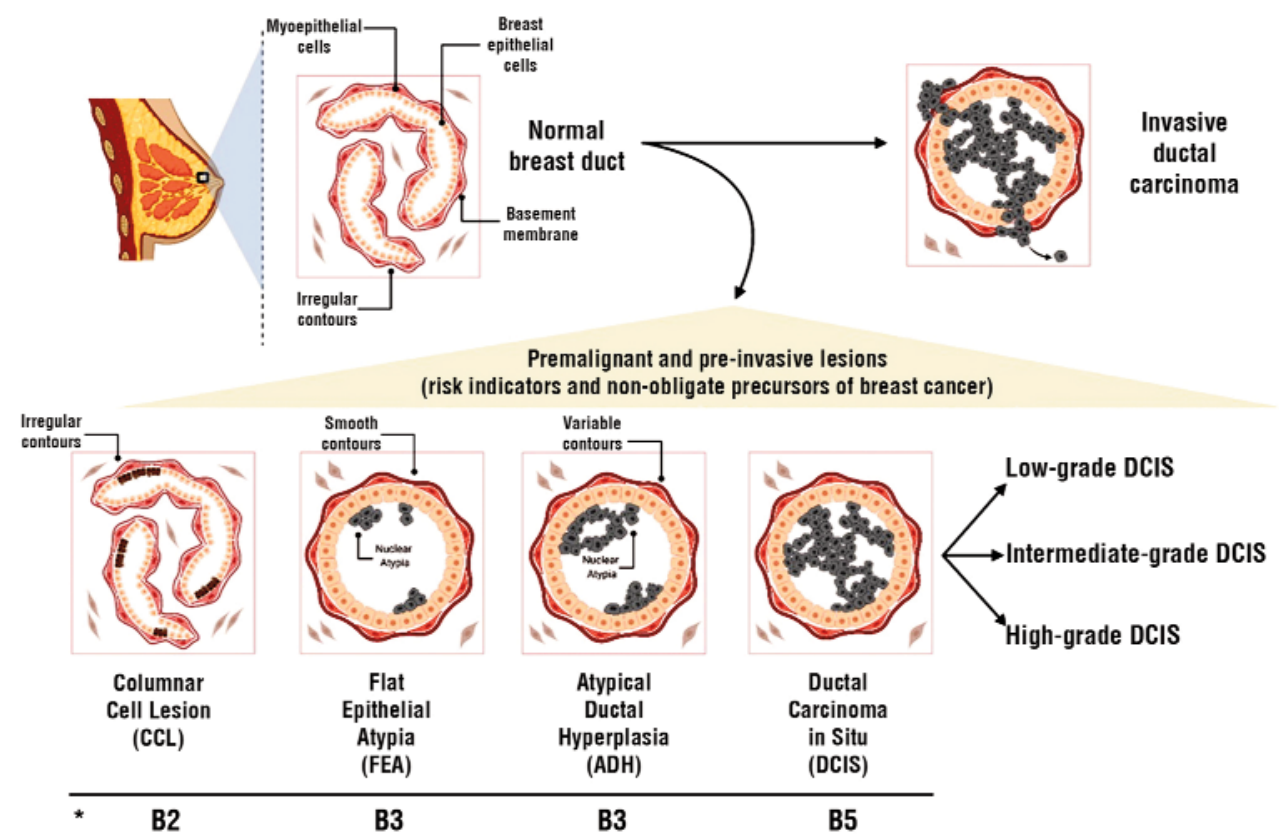

Figure 1. Premalignant and pre-invasive lesions of the breast belong to a complex and heterogeneous group of lesions and represent a matter of remarkable interest from both clinical and biological standpoints. The goal of therapy of DCIS is to prevent the occurrence of an invasive breast cancer.

*European guidelines for quality assurance in breast cancer screening and diagnosis. Created with Biorender.com. 
invasive $\mathrm{BC}$ and after diagnosis most of them undergo treatment similar to invasive disease. However, these treatments have not been shown to impact on survival, raising the concern of potential overtreatment (5). Ductal carcinoma in situ treatment is mainly represented by surgery and radiotherapy, which are covered by other authors in this issue.

According to the most recent guidelines, the only recommended systemic treatment for HR-positive DCIS is adjuvant endocrine therapy (ET), since the low risk of relapse of this neoplasm does not justify the indication to chemotherapy $(4,6)$. An analysis performed in 2015 on the National Cancer Database showed that $46 \%$ of patients affected by HR-positive DCIS receives ET as adjuvant treatment (7).

Here we discuss the results of the most relevant clinical trials enrolling DCIS patients in adjuvant and in preoperative setting; in addition, we report the chemoprevention studies in which ET demonstrated to reduce the risk of DCIS in patients with increased chances of $\mathrm{BC}$ occurrence.

\section{Endocrine Therapy}

\section{Adjuvant ET}

According to NCCN guidelines, ET should be considered in patients with HR-positive DCIS who underwent breast conserving surgery plus radiotherapy or surgery alone (4). The suggested duration of ET is 5 years, administering tamoxifen in premenopausal patients and tamoxifen or aromatase inhibitors (AI) in post-menopausal patients, considering the latter the preferential choice in patients aged less than 60 and/or having thromboembolic concerns (4).

In the National Surgical Adjuvant Breast and Bowel Project (NSABP) B-24 protocol, 1804 patients affected by DCIS were randomized to receive adjuvant tamoxifen $20 \mathrm{mg} / \mathrm{die}$, a selective estrogen receptor modular (SERM), or placebo for five years after completion of local treatment (lumpectomy and radiotherapy), regardless of the $\mathrm{HR}$ status (8). In the tamoxifen group, a significant $43 \%$ reduction of invasive $\mathrm{BC}$ events and a significant 31\% decrease of non-invasive $\mathrm{BC}$ events were detected after five years follow-up (8). More recently, a retrospective study on the same patients evaluated the effectiveness of tamoxifen according to HR status: estrogen receptor (ER) positive DCIS patients who received tamoxifen had a lower risk of developing any form of $\mathrm{BC}$ (hazard ratio (HR) $0.58, \mathrm{p}=0.001)$, invasive $\mathrm{BC}(\mathrm{HR} 0.53, \mathrm{p}=0.005)$ and any contralateral BC (HR 0.5, p=0.02) (9). Contrariwise, the reduction in any DCIS, contralateral and/or ipsilateral DCIS, any ipsilateral cancer, ipsilateral and/or contralateral invasive $\mathrm{BC}$ occurrence, even if present, was not statistically significant (9). As expected, no differences were detected in ER negative patients (9).

Another large prospective clinical trial exploring the role of adjuvant radiotherapy and tamoxifen in DCIS was the UK/ANZ DCIS trial, whose results reported a slight although not statistically significant advantage in the tamoxifen group considering all new BC events among the 1701 DCIS patients enrolled (HR 0.83, 95\% CI 0.64-1.06); on the other side, a reduction in all DCIS was highlighted (HR 0.68, CI 0.49-0.96), while no reduction in invasive BC was showed (HR 1.11, CI 0.761.63) (10). The long-term follow up analysis of this trial showed that patients who received tamoxifen had fewer $\mathrm{BC}$ events (10 years reduction 6.5\%) and ipsilateral DCIS, but no differences were detected in ipsilateral invasive BC development (11). Nevertheless, the benefit in terms of $\mathrm{BC}$ events given by tamoxifen was present only in patients who did not receive radiotherapy $(\mathrm{p}=0.001)$, while absent in patients who underwent radiotherapy $(\mathrm{p}=0.8)(11)$.

A Cochrane metanalysis published in 2012 including NSABP B-24 and UK/ANZ trials demonstrated a trend towards reduction of new primary invasive ipsilateral carcinomas for DCIS patients receiving adjuvant tamoxifen compared to patients who do not receive it (HR 0.79, 95\% CI 0.62-1.01), while the risk of developing a contralateral $\mathrm{BC}$ is significantly lower in the same group of patients (relative risk (RR) 0.57; 95\% CI 0.39- 
0.83) (12). Moreover, the risk of DCIS recurrence is reduced in patients who underwent tamoxifen treatment, both in ipsilateral (HR $0.75 ; 95 \%$ CI 0.61 to 0.92 ) and contralateral breast (RR 0.50; 95\% CI 0.28 to 0.87) (12). Consistently with the results of the single studies, the risk of overall mortality does not depend on tamoxifen assumption (RR 1.11; 95\% CI 0.89 to 1.39 ) (12). No clear statement is inferable with regard to adverse events related to tamoxifen, as the necessary information was not available to the authors (12).

The posology of tamoxifen in both NSABP B-24 and UK/ANZ trials was $20 \mathrm{mg} /$ die, which is not always well tolerated by patients and may leads to adverse events (13). For this reason, a randomized, placebo controlled clinical trial evaluated the administration of low-dose tamoxifen $(5 \mathrm{mg} /$ die $)$ for three years in 500 patients with breast intraepithelial neoplasms (69\% DCIS) (14). A reduction in breast neoplastic events was detected in patients who received tamoxifen ( $\mathrm{HR}, 0.48$; $95 \%$ CI, 0.26 to 0.92) (14). Based on this evidence, the administration of tamoxifen 5 $\mathrm{mg} /$ die for three years could be considered in patients who do not tolerate the standard posology.

The results of ATAC trial, in which an improvement in terms of disease-free survival (DFS), time to recurrence, time to distant recurrence and safety was demonstrated in early BC post-menopausal patients receiving anastrozole compared to tamoxifen, led to the planning of new clinical trials. In fact, ET other than tamoxifen have been tested in order to identify more effective and/or safer drugs. In the NSABP B-35 trial 3104 postmenopausal patients affected by HR-positive DCIS were randomized to receive adjuvant anastrozole or tamoxifen after lumpectomy and whole breast irradiation $(15,16)$, demonstrating a prolonged BC-free interval in the anastrozole group. (HR 0.73 95\% CI 0.56-0.96, $\mathrm{p}=0.0234$ ) (15). Interestingly, the difference between the two groups became evident after 5 years and, even more importantly, the benefit of anastrozole was significant only in patients less than 60 years old (15). The esti- mated 10-year overall survival was roughly $92 \%$ for both groups (15). Concerning the safety profile, adverse events were comparable in patients receiving tamoxifen and anastrozole, with exception of thrombotic and embolic events, which occurred more often during tamoxifen treatment (15).

The comparison between anastrozole and tamoxifen has been explored also in the IBIS-II DCIS trial: 2980 HR-positive postmenopausal DCIS patients were randomized to receive anastrozole or tamoxifen (17). After a 7-year follow-up, no statistically significant difference in overall recurrence was detected between the two groups (HR 0.89, 95\% CI 0.64-1.23) (17). Nevertheless, a slight advantage with anastrozole was underlined and, taking into account that the number of events in IBIS-II DCIS trial was lower than expected, these results do not contrast with the ones of NSABP B-35 trial (17). Furthermore, adverse events observed in each treatment arm were consistent with the safety profile of the two drugs: fractures, musculoskeletal events, hypercholesterolemia, and cerebrovascular accidents were more common with anastrozole, while muscle spasm, gynecological cancers and symptoms, vasomotor symptoms, and deep vein thromboses were the most common adverse events observed with tamoxifen (17).

Recently, a cost-effectiveness analysis on adjuvant treatment of DCIS showed that ET with tamoxifen or AI is likely to represent a suboptimal therapeutic strategy (18). In facts, the quality-adjusted life years (QALYs) are fewer for patients receiving ET than for the ones undergoing observation, because of the marginal benefit in risk reduction at the cost of a largely impaired quality of life (18). Radiotherapy is, on the contrary, costeffective for standard risk patients, while observation is cost-effective for good-risk patients, defined as patients with $\leq 2.5 \mathrm{~cm}$ diameter DCIS, low to intermediate grade, and mammographically detected lesions with final margins $\geq 3 \mathrm{~mm}$ (18).

An algorithm summarizing DCIS postsurgical treatment is illustrated in Fig. 2. 


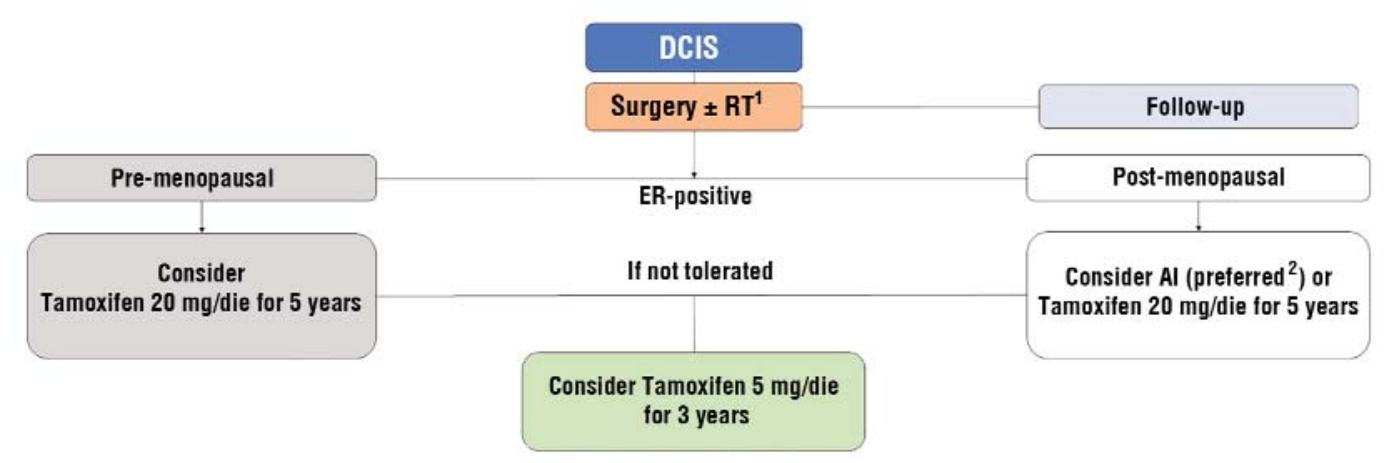

Figure 2. Algorithm for DCIS adjuvant treatment.

1. RT after breast conserving surgery, could be omitted in case of low risk DCIS due to favorable clinicopathological features and/or Oncotype DX DCIS Recurrence Score $<39$ or between 39 and 54 (to be thoroughly discussed with the patient).

2. Patients under 60 years or with thromboembolic concerns.

Legend: $\mathrm{DCIS}$ = Ductal Carcinoma in Situ; $\mathrm{RT}$ = radiotherapy; $\mathrm{ER}$ = Estrogen Receptor; AI = Aromatase Inhibitor.

\section{Neoadjuvant ET}

A potential role for hormonal manipulation before surgery in patients with DCIS was firstly demonstrated by Boland et al., almost 20 years ago (19). In a retrospective study including 108 patients receiving hormone replacement therapy (HRT), they observed a significant Ki-67 reduction from biopsy to surgery in patients that stopped HRT (mean Ki-67 9.95\% and 5.06\% on core biopsy and at surgery, respectively, p<0.01), whereas Ki-67 from biopsy to surgery was similar in patients that continued HRT (19).

The CALGB 40903 (Alliance) trial addressed the feasibility of 6 months of preoperative letrozole in postmenopausal patients (20). Seventy patients completed the planned treatment cycle with letrozole $2.5 \mathrm{mg}$ daily and 59 underwent surgery, with 9 patients (15\%) showing no residual DCIS, 50 (85\%) persisting DCIS and 6 (10\%) harboring invasive disease (20). The tumor volume, assessed by breast magnetic resonance imaging, decreased of $61 \%$ and $71.7 \%$ after 3 and 6 months of letrozole therapy, respectively (20). An analysis of ER, Progesterone receptor (PgR) and Ki-67 status was also performed, comparing pre-ET and post-surgical values. As expected, a reduction was detected in the three biomarkers: the ER Histo-score decreased by $15(\mathrm{p}=0.005)$, the median PR Histo- score by $85(\mathrm{p}<0.001)$, and the median Ki-67 score by $6.3 \%(\mathrm{p}=0.007)(20)$.

\section{Chemoprevention}

The role of ET in reducing the incidence of both invasive and in situ breast lesions has been evaluated in several clinical trials, utilizing SERM, tamoxifen in primis, and then AI.

The NSABP P- 1 trial compared tamoxifen to placebo in 13388 patients estimated to have a 5 -year risk of $1.66 \%$ or more to develop BC (21). The reduction of invasive $\mathrm{BC}$ incidence was significant: from 42.5 per 1000 in the placebo group to 24.8 per 1000 in the tamoxifen group $(p<0.001)(21)$. Adecreased incidence was noticed also considering noninvasive lesions (DCIS and LCIS), for which the risk ratio was 0.63 (95\% CI $=0.45$ to 0.89$)$ in patients treated with tamoxifen (21).

In the IBIS-I trial, 7154 women judged to have an increased risk of $\mathrm{BC}$ development were randomized to receive tamoxifen for five years or placebo (22). Consistently with NSABP P-1 trial's results, tamoxifen reduced the risk of any $\mathrm{BC}$ occurrence (HR 0.71; 95\% CI $0.60-0.83, \mathrm{p}<0.0001$ ), including DCIS (23), at a long term follow up. In fact, 16 cases of DCIS were detected in tamoxifen group vs 5 in placebo group (Odds Ratio $0.31 ; 95 \%$ CI $0.12-0.82)(23)$.

In the MORE trial, raloxifene was tested in 
the same setting, with similar results (24). Considered together, SERMs demonstrated to reduce the occurrence of both invasive and noninvasive breast lesions in patients accounted to have increased risk to develop $\mathrm{BC}$, but at the price of adverse events which impact consistently on the quality of life of patients.

In this perspective, AIs were investigated as a potential alternative to SERMs with a more favorable toxicity profile. For instance, five years of anastrozole demonstrated to be effective in reducing the cumulative incidence of BC (including DCIS) versus placebo (HR 0.47, 95\% CI 0.32-68; p<0.0001) (25).

Similarly, exemestane was effective in postmenopausal women with a Gail 5-year risk score higher than $1.66 \%$ or other increased risk conditions, with a yearly incidence of invasive plus noninvasive (DCIS) $\mathrm{BC}$ of $0.35 \%$ on exemestane and $0.77 \%$ on placebo $(\mathrm{HR}=0.47$; $95 \%$ CI: 0.27 to $0.79 ; p=0.004)(26)$.

\section{HER2-Directed Therapy}

HER2 overexpression is comparable in DCIS and in invasive $\mathrm{BC}$ (27), thus an eventual role of HER2-directed therapy was investigated in a certain number of clinical trials.

A phase II trial investigated the biological and immunological effects of a single preoperative trastuzumab administration in HER2positive DCIS, but, unfortunately, no clear histologic changes ascribable to response to the treatment were detected, nor variations in $\mathrm{Ki}-67$ values between the patients who received trastuzumab and the ones who did not (28). Nevertheless, the antibody-dependent cell mediated cytotoxicity (ADCC) was enhanced in all the patients undergoing trastuzumab treatment (28).

A retrospective study including patients who underwent neoadjuvant chemotherapy plus trastuzumab for invasive BC associated with DCIS showed that 7 out of 16 patients included had a complete regression of the DCIS component, 7 had a pCR, while 2 patients showed a complete regression of DCIS but persisting invasive BC (29).
The phase III NSABP B-43 explored the administration of two cycles of trastuzumab during breast irradiation in DCIS patients after breast conserving surgery (30). A group of 2014 patients with HER2-positive DCIS were randomized to receive radiotherapy alone or radiotherapy plus trastuzumab, adding five years of tamoxifen in HR-positive patients in both groups (31). At primary definitive analysis, 114 ipsilateral BC events occurred, 63 in the radiotherapy arm and 51 in the radiotherapy plus trastuzumab arm (HR=0.81; 95\% CI: 0.56-1.17; $\mathrm{p}=0.26) \quad(31)$. Taking into account only the 76 DCIS events, 45 occurred in the radiotherapy arm and 31 in the radiotherapy plus trastuzumab arm $(\mathrm{HR}=$ 0.68; 95\% CI: 0.43-1.08; p=0.11) (31). As a consequence, the study did not meet its endpoints of reducing ipsilateral $\mathrm{BC}$ recurrence by $36 \%$ (31).

For the abovementioned reasons, anti-HER2 treatment is not recommended as adjuvant or neoadjuvant treatment for HER2-positive DCIS. Moreover, according to international guidelines, HER2 should not be tested in patients with DCIS outside clinical trials (32).

\section{Conclusions}

The role of ET in the treatment of HR-positive $\mathrm{BC}$ is well-established. The results of the ET adjuvant clinical trials in DCIS patients indicate that 5 years ET with tamoxifen (20 $\mathrm{mg} / \mathrm{die}$ ) or AI, in premenopausal and postmenopausal patients, respectively, should be considered in ER-positive DCIS. Indeed, ET demonstrated to reduce the bilateral $\mathrm{BC}$ risk in patients treated with breast conserving surgery as well as the contralateral risk in patients who underwent mastectomy, if the primary tumor shows positivity for ER (4).

Conversely, no evidence of efficacy emerged from the completed clinical trials employing HER2-directed therapies in DCIS patients. Chemotherapy also does not have any role in the management of DCIS because of its unfavorable toxicity and safety profile which do not allow its use in a disease with such good prognosis. 
Nevertheless, whether to administer a systemic treatment for DCIS or not should be tailored to the patient, taking into account his risk profile, individual characteristics as well as his personal preferences. Of course, a thorough discussion with the patient about the potential advantages and risks of each scenario is recommended. In fact, the absolute benefit of 5 years of treatment is modest and, as shown in the abovementioned metaanalysis, 15 patients would need to be treated to prevent one recurrence (12). Considering the absence of any survival advantage, the balance between potential adverse events and benefit in terms of reduced risk of recurrence should be extensively discussed with patients to reach a well-informed shared decision.

\section{Authors Contributions}

All the authors read and approved the final version of the manuscript.

\section{Conflicts of Interest}

EC, CC, MR, FG, GA, PZ, EN, SM, PT, and JU have no conflict of interest to disclose.

\section{Competing Interests}

GC reports honoraria from Ellipses Pharma, consulting or advisory role for Roche/ Genentech, Pfizer, Novartis, Lilly, Foundation Medicine, Bristol Myers Squibb, Samsung, AstraZeneca, Daichi-Sankyo, Boehringer Ingelheim, GSK, Seattle Genetics, speakers' bureau from Roche/Genentech, Novartis, Pfizer, Lilly, Foundation Medicine, Samsung, Daiichi Sankyo, research funding from Merck (Inst), and travel/accommodations expenses from Roche/Genentech, Pfizer.

\section{References}

1. American Cancer Society. American Cancer Society: Breast Cancer Facts \& Figures 2019-2020. Atlanta, GA 2019. https://www.cancer.org/content/dam/ cancer-org/research/cancer-facts-and-statistics/breast-cancer-facts-andfigures/breast-cancer-facts-and-figures-2019-2020.pdf (accessed June 8, 2021).

2. Miligy IM, Toss MS, Shiino S, Oni G, Syed BM, Khout H, et al. The clinical significance of oestrogen receptor expression in breast ductal carcinoma in situ. Br J Cancer 2020;123:1513-20.

3. Yan M, Bomeisl P, Gilmore H, Harbhajanka A. Clinicopathological Followup of Breast DCIS Diagnosed on Biopsies: A Single Institutional Study of 575 Patients. Int J Surg Pathol. doi: 10.1177/10668969211012088. Epub 2021 Apr 23.

4. Abraham J, Aft R, Agnese D, Allison KH, Anderson B, Blair SL, et al. NCCN Guidelines Version 4.2021 Breast Cancer. 2021.

5. Narod SA, Iqbal J, Giannakeas V, Sopik V, Sun P. Breast cancer mortality after a diagnosis of ductal carcinoma in situ. JAMA Oncol. 2015;1(7): 888-96.

6. Cardoso F, Kyriakides S, Ohno S, Penault-Llorca F, Poortmans P, Rubio IT, et al. Early breast cancer: ESMO Clinical Practice Guidelines for diagnosis, treatment and follow-up. Ann Oncol. 2019;30(8):1194-1220.

7. Flanagan MR, Rendi MH, Gadi VK, Calhoun KE, Gow KW, Javid SH. Adjuvant Endocrine Therapy in Patients with Ductal Carcinoma In Situ: A Population-Based Retrospective Analysis from 2005 to 2012 in the National Cancer Data Base. Ann Surg Oncol. 2015;22(10):3264-72.

8. Fisher B, Dignam J, Wolmark N, Wickerham DL, Fisher ER, Mamounas E, et al. Tamoxifen in treatment of intraductal breast cancer: National surgical adjuvant breast and bowel project B-24 randomised controlled trial. Lancet. 1999:353(9169):1993-2000.

9. Allred DC, Anderson SJ, Paik S, Wickerham DL, Nagtegaal ID, Swain SM, et al. Adjuvant tamoxifen reduces subsequent breast cancer in women with estrogen receptor-positive ductal carcinoma in situ: A study based on NSABP protocol B-24. J Clin Oncol. 2012;30(12):1268-73.

10, Houghton J, George WD, Cuzick J, Duggan C, Fentiman IS, Spittle M, et al. Radiotherapy and tamoxifen in women with completely excised ductal carcinoma in situ of the breast in the UK, Australia, and New Zealand: Randomised controlled trial. Lancet. 2003;362(9378):95-102.

11. Cuzick J, Sestak I, Pinder SE, Ellis IO, Forsyth S, Bundred NJ, et al. Effect of tamoxifen and radiotherapy in women with locally excised ductal carcinoma in situ: Long-term results from the UK/ANZ DCIS trial. Lancet Oncol. 2011;12(1):21-9. Epub 2010 Dec 7.

12. Staley H, McCallum I, Bruce J. Postoperative tamoxifen for ductal carcinoma in situ. Cochrane Database Syst Rev. 2012;10:CD007847.

13. Condorelli $\mathrm{R}$, Vaz-Luis I. Managing side effects in adjuvant endocrine therapy for breast cancer. Expert Rev Anticancer Ther. 2018;18(11):1101-1112.

14. DeCensi A, Puntoni M, Guerrieri-Gonzaga A, Caviglia S, Avino F, Cortesi L, et al. Randomized placebo controlled trial of low-dose tamoxifen to prevent local and contralateral recurrence in breast intraepithelial neoplasia. J Clin Oncol. 2019;37(19):1629-1637.

15. Margolese RG, Cecchini RS, Julian TB, Ganz PA, Costantino JP, Vallow LA, et al. Anastrozole versus tamoxifen in postmenopausal women with ductal carcinoma in situ undergoing lumpectomy plus radiotherapy (NSABP B-35): A randomised, double-blind, phase 3 clinical trial. Lancet. 2016; 387(10021):849-56. Epub 2015 Dec 11.

16. Cuzick J, Sestak I, Baum M, Buzdar A, Howell A, Dowsett M, et al. Effect of anastrozole and tamoxifen as adjuvant treatment for early-stage breast cancer: 10-year analysis of the ATAC trial. Lancet Oncol. 2010;11(12): $1135-41$.

17. Forbes JF, Sestak I, Howell A, Bonanni B, Bundred N, Levy C, et al. Anastrozole versus tamoxifen for the prevention of locoregional and contralateral breast cancer in postmenopausal women with locally excised ductal carcinoma in situ (IBIS-II DCIS): A double-blind, randomised controlled trial. Lancet. 2016;387(10021):866-73. Epub 2015 Dec 11.

18. Gupta A, Jhawar SR, Sayan M, Yehia ZA, Haffty BG, Yu JB, et al. CostEffectiveness of Adjuvant Treatment for Ductal Carcinoma In Situ. J Clin Oncol. 2021:39(21):2386-2396. Epub 2021 May 21.

19. Boland GP, Mckeown A, Chan KC, Prasad R, Knox WF, Bundred NJ. Biological response to hormonal manipulation in oestrogen receptor positive ductal carcinoma in situ of the breast. Br J Cancer. 2003; 89(2): 277-83.

20. Shelley Hwang E, Hyslop T, Hendrix LH, Duong S, Bedrosian I, Price E, et al. Phase II single-arm study of preoperative letrozole for estrogen receptor-positive postmenopausal ductal carcinoma in situ: CALGB 40903 (Alliance). J Clin Oncol. 2020;38(12):1284-1292.

21. Fisher B, Costantino JP, Wickerham DL, Cecchini RS, Cronin WM, 
Robidoux A, et al. Tamoxifen for the prevention of breast cancer: Current status of the National Surgical Adjuvant Breast and Bowel Project P-1 study. J Natl Cancer Inst. 2005;97(22):1652-62.

22. Cuzick J, Forbes J, Edwards R, Baum M, Cawthorn S, Coates A. First results from the International Breast Cancer Intervention Study (IBIS-I): A randomised prevention trial. Lancet. 2002;360(9336):817-24.

23. Cuzick J, Sestak I, Cawthorn S, Hamed H, Holli K, Howell A, et al. Tamoxifen for prevention of breast cancer: Extended long-term follow-up of the IBIS-I breast cancer prevention trial. Lancet Oncol. 2015;16(1):67-75. Epub 2014 Dec 11.

24. Cauley JA, Norton L, Lippman ME, Eckert S, Krueger KA, Purdie DW, et al. Continued breast cancer risk reduction in postmenopausal women treated with raloxifene: 4-Year results from the MORE trial. Breast Cancer Res Treat. 2001;65(2):125-34.

25. Cuzick J, Sestak I, Forbes JF, Dowsett M, Knox J, Cawthorn S, et al. Anastrozole for prevention of breast cancer in high-risk postmenopausal women (IBIS-II): An international, double-blind, randomised placebocontrolled trial. Lancet. 2014;383(9922):1041-8. Epub 2013 Dec 12.

26. Goss PE, Ingle JN, Alés-Martínez JE, Cheung AM, Chlebowski RT, Wactawski-Wende J, et al. Exemestane for breast-cancer prevention in postmenopausal women. N Engl J Med. 2011:364(25):2381-91.

27. Miligy IM, Toss MS, Gorringe KL, Lee AHS, Ellis I0, Green AR, et al. The clinical and biological significance of HER2 over-expression in breast ductal carcinoma in situ: a large study from a single institution. $\mathrm{Br} \mathrm{J}$ Cancer. 2019;120(11):1075-1082.

28. Kuerer HM, Buzdar AU, Mittendorf EA, Esteva FJ, Lucci A, Vence LM, et al. Biologic and immunologic effects of preoperative trastuzumab for ductal carcinoma in situ of the breast. Cancer. 2011;117(1):39-47. Epub 2010 Aug 24.

29. Parham DM, Pinder SE. The impact of human epidermal growth factor receptor 2 neoadjuvant monoclonal antibody (trastuzumab) therapy in ductal carcinoma in situ of the breast. Histopathology. 2017;70(6): 1009-1011.

30. Siziopikou KP, Anderson SJ, Cobleigh MA, Julian TB, Arthur DW, Zheng P, et al. Preliminary results of centralized HER2 testing in ductal carcinoma in situ (DCIS): NSABP B-43. Breast Cancer Res Treat. 2013;142(2):415-21.

31. Cobleigh MA, Anderson SJ, Siziopikou KP, Arthur DW, Rabinovitch R, Julian TB, et al. Comparison of Radiation With or Without Concurrent Trastuzumab for HER2-Positive Ductal Carcinoma In Situ Resected by Lumpectomy: A Phase III Clinical Trial. J Clin Oncol. 2021:39(21):2367-2374.

32. Wolff AC, Elizabeth Hale Hammond M, Allison KH, Harvey BE, Mangu PB, Bartlett JMS, et al. Human epidermal growth factor receptor 2 testing in breast cancer: American society of clinical oncology/ college of American pathologists clinical practice guideline focused update. J Clin Oncol. 2018; 36(20):2105-2122 